\title{
Respuesta morfológica y comparación multiparámetro de alternativas de extracción de aceite de microalgas para la obtención de biodiesel y co-productos
}

\section{Morphologycal response and multiparameter comparison of microalgae oil extraction alternatives for obtaining biodiesel and co-products}

\author{
Ángel Darío González-Delgado', Viatcheslav Kafarov² \\ ${ }^{1}$ Candidato a Doctor en Ingeniería Química, Centro de Investigación para el Desarrollo Sostenible en Industria y Energía, Escuela de Ingeniería \\ Quimica, Universidad Industrial de Santander (UIS), Cra. 27 Calle 9, Bucaramanga, Colombia, correo: cisyc@uis.edu.co \\ ${ }^{2}$ Doctor en Ingeniería Química, Centro de Investigación para el Desarrollo Sostenible en Industria y Energía, Escuela de Ingeniería Química, \\ Universidad Industrial de Santander (UIS), Cra. 27 Calle 9, Bucaramanga, Colombia.
}

Recibido 11/12/12, Aceptado 08/04/2013

\section{RESUMEN}

La biomasa de microalgas se perfila como un cultivo energético de gran interés a nivel mundial por su potencial para la obtención de biocombustibles y otros productos de valor agregado y para el desarrollo de procesos de biorefinería debido a su variada composición y sus altas productividades por unidad de área. Varias alternativas de extracción y transformación de metabolitos de microalgas están siendo estudiadas para el desarrollo de nuevas tecnologías de aprovechamiento de esta materia prima. Entre estas, la extracción del aceite de microalgas es particularmente importante ya que es una etapa clave en cadenas de producción de biodiesel a partir de microalgas y su eficiencia contribuye en gran medida con la eficiencia global del proceso.

En este estudio se realiza una comparación en términos de eficiencia, costos de extracción, requerimientos energéticos y toxicidad de cinco métodos de extracción de aceite de microalgas a escala laboratorio utilizando cinco cepas de microalgas de bioprospección nacional. Los métodos evaluados fueron Extracción con solvente asistida por homogenización a alta velocidad (SHE), Extracción con solvente de reflujo continuo (SCE), Extracción con hexano (HBE) y ciclohexano (CBE), y Extracción de aceite utilizando la mezcla etanol-hexano (EHE), mientras que las cepas de microalgas utilizadas fueron Closterium sp., Amphiprora sp., Navicula sp., Nannochloropsis sp. y Guinardia sp., asimismo, se estudió la respuesta morfológica de las cepas mencionadas a los distintos métodos de extracción por medio de microscopía óptica. Los resultados muestran que aunque no hay un método que tenga el mejor desempeño desde todos los puntos de vista evaluados, en términos de eficiencia los métodos SCE, SHE y HBE son los más promisorios, mientras que el método HBE se muestra como el más conveniente para utilizar a escala laboratorio de manera global y como una tecnología emergente para la extracción de aceite de microalgas a gran escala.

Palabras Clave: Microalgas, Extracción, Eficiencia, Costos, Requerimientos energéticos, Toxicidad.

\begin{abstract}
Microalgae biomass emerges as an energy crop of great interest worldwide owing to its potential for obtaining biofuels and high value products and for the development of biorefinery processes owing to their varied composition and high biomass productivities per area unit. Several alternatives of microalgal metabolites extraction and transformation are being studied for the development of novel technologies for biomass using. Microalgae oil extraction is particularly important because is a key stage in microalgal biodiesel production chains and their efficiency contributes significantly to global process efficiency.

In this study, a comparison of five oil extraction methods in lab-scale, taking into account extraction efficiency, energy consumption, costs of extraction and toxicity was made using five national bioprospecting microalgae strains. Methods evaluated were Solvent extraction with high speed homogenization (SHE), Continuous efflux solvent extraction (SCE), Hexane based extraction (HBE), Cyclohexane based extraction (CBE) and Ethanol-hexane extraction (EHE), microalgae strains used were Closterium sp., Amphiprora sp., Navicula sp., Nannochloropsis sp., and Guinardia sp., morphologycal response of strains to oil extraction methods was also evaluated using optic microscopy. Results shows that although there is not an unique oil extraction method with the best performance in all evaluated criteria, SCE, SHE and HBE methods presents high oil yields, while HBE method is the more convenient in global terms for use in lab scale and appears as an emerging technology for microalgae oil extraction in large scale.
\end{abstract}

Keywords: Microalgae, Oil extraction, Efficiency, Costs, Energy requirements, Toxicity. 


\section{INTRODUCTION}

Currently, there are two increasing general worries related with fossil-derived liquid fuels; global warming linked with gas emissions produced after its combustion, and high prices of petroleum. For these reasons, research about biofuels production from renewable resources is increasing [1]. Energy production, goods and services are necessary, but they must be socially, economically and environmentally sustainable [2]. Microalgae is an energy source that offers considerable amounts of fuel from small crop areas and lower production costs, which further helps in the mitigation of global warming; its culturing tolerates high concentrations of $\mathrm{CO}_{2}$ and decreases the amount of nitrogen oxides released into the atmosphere. The biodiesel-from-microalgae production chain is composed by the stages of cultivation, harvesting of biomass, drying, lipid extraction and oil transesterification [3].

However, biodiesel-from-microalgae production chain is still away of sustainability by several factors, in energy terms, comparison of energy demands for microalgal biodiesel production shows that energy required in all stages of production process is more than energy produced by third generation biodiesel [4], In this sense, results of studies related to bioprospecting, exploration and production of microalgae biomass made by research centers as the NREL In United States, the CISOT and CIEMAT in Spain, the CIDES and ICP in Colombia [5], among others, concludes that production of biodiesel from microalgae can be economically viable if total biomass components are used for obtaining biofuels and high value products and the concept of biorefinery is incorporated.

The International Energy Agency says that biorefining is processing biomass in a sustainable manner within a spectrum of marketable products and energy, this concept can be extended, according to Cherubini [6], to a laboratory or a set of laboratories that integrates biomass transformation processes and equipment for the production of fuels for transportation, energy and chemicals. The biorefinery concept has been identified as the most promising for the creation of an industry based on biomass. However, this concept has not been applied so far to the biomass of microalgae define a path-oriented technology for the production of biofuels and high added value products based on the physicochemical characterization of a promising species, a microalgae based biorefinery must take into account several issues for its sustainability as water requirements, production costs, environmental impacts and process efficiency [7].

Numerous variables in all production chain stages are being analyzed, the extraction of carbohydrates, lipids, pigments, proteins and special substances from microal- gae biomass is under research for obtaining several bioproducts [8] focusing on the use of multifunctional processes for simultaneous extraction separation and transformation of two or more desired [9], or in optimization of operating conditions and routes for obtaining a desired specific metabolite, pigments extraction can be made by cell breaking, solvent extraction and centrifugation, and purification is made using microfiltration, drying or liofilization [10], reducing sugars can be obtained by hydrolysis reaction with simultaneous cell wall disruption for oil [11], proteins are extracted for use as fertilizer [12], animal feed supplement [13] and substrate for fermentation [14] .

For microalgae lipid extraction, different methodologies are under study in lab-scale which can be divided in physical methods as ultrasound-assisted extraction, microwave-assisted extraction, autoclave, cell homogenizers, ball mills and pressing systems among others, chemical methods as supercritical fluids and solvent-based techniques and enzymatic methods [15], however, several studies must be developed in order to find the best large scale process that allows an effective oil extraction in terms of efficiency, purity of product desired, energy requirements, costs and environmental impacts.

The aim of this work, is to compare five lab-scale oil extraction methodologies previously developed using five native microalgae strains taking into account besides extraction efficiency, additional aspects as toxicity of solvents used, energy consumption, and operative costs for further development of a microalgae-based biorefinery.

\section{METHODOLOGY}

\subsection{Microalgae Biomass}

Native microalgae strains were supplied by the Morrosquillo Corporation (Punta Bolivar, Colombia), biomass was grown in $\mathrm{f} / 2$ medium, harvested by flocculation, sundried and refrigerated until use. Characterization of different strains was provided by the Colombian Petroleum Institute ICP-ECOPETROL. The genera used for comparison were Navicula sp., Nannocloropsis sp., Guinardia sp., Closterium sp. and Amphiprora sp.

\subsection{Oil extraction methods}

Solvent-based oil extraction methods evaluated (hexane and cyclohexane based methods, solvent extraction with high speed homogenization, continuous reflux solvent extraction and ethanol-hexane method) were designed and adjusted by authors in previous works [16], finding the best operating conditions as the first stage of cell wall disruption as second stage of solvent oil extraction and lipid purification, for all methods cell disruption is intended to 
destroy the microalgae cell wall to facilitate the recovery of intracellular products and obtain greater amounts of lipids, methods were performed as follows:

Continuous reflux solvent extraction (SCE). This is a multiple-extraction procedure that consists in a first cell disruption stage in which $5 \mathrm{~g}$ of biomass are mixed with water, methanol and sulphuric acid in a 1:5:0.8:0.32 ratio, mixture is placed in a $25 \mathrm{~L}$ Autoclave by $4 \mathrm{~h}$, water-soluble compounds in the cell were dissolved by the acid and formed a compound called solubilized mass, which is separated from the non-polar phase by vacuum filtering, followed by a neutralization of the biomass to stop cell degradation and drying at $105^{\circ} \mathrm{C}$ during 4 hours, for solvent extraction, a typical Soxhlet extractor with 45/50 outer/upper and 24/40 lower/inner joint for $250 \mathrm{~mL}$ capacity was used, pretreated dry biomass was put in a cartridge and solvent was heated to boiling point, then condensing it on the cartridge of biomass, giving way to the solid-liquid extraction of present lipids, the process described is repeated for 16 hours, during solvent extraction, the amount of biomass and the ratio biomass/solvent were kept constant, solvent used for this method was hexane. After extraction, extract-solvent mixture was filtered, distilled and the remnant solvent was evaporated. Total lipids were also quantified by gravimetric methods [17].

Ethanol/Hexane method (EHE). This method is based in a lipid extraction method developed by Fajardo AR, Cerdan LE, Medina AR, Fernandez FGA, Moreno PAG \& Grima EM [18], this procedure uses two solvents for extraction and subsequent purification of the extract. Ethanol is used in the first stage to recover the lipid content of microalgae; the crude oil obtained with ethanol contains unsaponifiable lipids, such as pigments, proteins, amino acids and other lipid and non-lipid contaminants. As a second step, the addition of water and hexane to the crude extract, obtained above, generates the formation of a biphasic system, in which lipids are transferred to the hexane phase, and the impurities are retained in the hydroalcoholic phase. This phase separation occurs due to the difference in solubility between solvents. It is performed by decanting and is repeated five times by adding more water and hexane to the hydroalcoholic phase. The proportion water content has been optimized to displace the equilibrium distributions of lipids to the hexane phase, for cell disruption a solution with $5 \mathrm{~g}$ of biomass and $0.5 \mathrm{~mol} \mathrm{~L}^{-1}$ of hydrochloric acid was prepared and subjected to a stirring speed of 500 rpm for 120 minutes at room temperature, subsequently, vacuum filtration was performed where the $\mathrm{pH}$ was raised about 6 or 7 with the addition of distilled water, thereby obtaining hydrolyzed biomass and water-soluble phase. Hydrolyzed biomass was dried to $105^{\circ} \mathrm{C}$ for $4 \mathrm{~h}$ [19].

Solvent extraction with high speed homogenization (SHE). This is a rapid and effective method, which mainly inclu- des the stages of strong homogenization, centrifugation and filtration, for its performance, methanol, chloroform and biomass are mixed in a mass ratio of 6:12:1 under environmental conditions, methanol is a polar solvent that dissolves polar lipids, on the other hand, chloroform is a nonpolar solvent which dissolves the neutral lipids present in the extraction and water is a polar solvent allows separate methanol/polar lipids phase of the chloroform/neutral lipids, the mixture is stirred and separated by filtration, obtaining a liquid phase with high percentage of lipids and a solid stream of biomass, liquid fluid is mixed with water in 4:1 ratio for phase separation, after that, hydrophilic/hydrophobic phases are separated using centrifugation for 15 minutes at $3400 \mathrm{rpm}$ the upper phase methanol/water from the centrifuge tube was removed while lower phase biomass/lipids Chloroform, was filtered by gravity. Finally, the lipid extract was allowed to volatilize to constant weight for its measurement, cell disruption in this method is achieved by mechanical action in homogenization [20].

Hexane and Cyclohexane based extraction (HBE and CBE respectively). In the first stage of cell disruption, $5 \mathrm{~g}$ of microalgae biomass are mixed with hydrochloric acid $0.5 \mathrm{~mol}$ $\mathrm{L}^{-1}$, mixture was stirred for 120 minutes at room temperature, after that, vacuum filtration was performed where the $\mathrm{pH}$ was raised about 6 or 7 with the addition of distilled water, finally, hydrolyzed biomass was dried to $105^{\circ} \mathrm{C}$ for $4 \mathrm{~h}$, for solvent extraction, biomass was mixed with fresh hexane or cyclohexane in a 1:20 ratio and stirred at $500 \mathrm{rpm}$ for $24 \mathrm{~h}$ in order to promote the solvent-biomass contact, finally, solvent-extract solution is separated from biomass by vacuum filtration and solvent is recovered by distillation [21].

Oil yield and lipid extraction efficiency. It was estimated the yields and efficiencies for each of the methods based on the gravimetric analysis done to each, oil yield in every test was calculated using the equation 1, from amount of biomass used and oil obtained. To calculate lipid extraction effectiveness, the term Relative Extraction Ratio is introduced, this ratio is defined as the lipid yield reached using any extraction method evaluated respect to lipid yield reached performing SHE method, which is used for total lipid determination, equation 2 was used for calculation of Relative Extraction Ratio.

$$
\text { Oil Yield }=\frac{\text { lipid extract weight }}{\text { total biomass weight }} * 100 \%
$$

$$
\text { Relative extraction ratio }=\frac{\text { Oild Yield }}{\text { total liped determined }} * 100 \%
$$




\subsection{Morphological response}

Observation in optical microscope is performed to the biomass of the five strains at objective100x before and after every procedure in order to see its influence in the cell and its damage on the morphology of the same.

\subsection{Comparison criteria}

\subsubsection{Energy requirements}

Energy from electric or heating services was estimated according to the electric power of the equipment used in each process and time spent in extraction procedure, calculations were made using equation 3 .

$$
\mathrm{E}_{\mathrm{met}}=\sum_{1}^{\mathrm{n}} \mathrm{P}_{\mathrm{eq}} \cdot \mathrm{t}_{\mathrm{et}}
$$

\subsubsection{Cost of extraction}

An estimate of the value of application of each method in lab-scale was calculated from the cost of solvents and volume used, as well as a percentage allocated to other materials which is equivalent to the $10 \%$ of the value and correspond to elements used performing the method such as filter paper and $\mathrm{pH}$ indicators. In the case of soxhlet extraction is added a term corresponding to the cost of water service according to its price under local conditions and flows.

$$
\mathrm{C}_{\mathrm{met}}=\sum_{1}^{\mathrm{m}} \mathrm{C}_{\text {slov }} \cdot \mathrm{V}_{\text {slov }}+\text { others }
$$

\subsection{Toxicity}

As all microalgae oil extraction methods evaluated in this study are solvent-based, toxicity is considered as a very important aspect of this study due to the implications of the use of these substances. The LD50\% was used as toxicity criteria. In methods with solvent mixtures for extraction, the solvent with lower LD50\% was taken as reference.The method whit higher DL50\% was considered more tolerable in comparison to the others.

\section{RESULTS AND DISCUSSION}

According to the characterization of studied microalgae strains shown in table 1, Amphiprora sp. presents the highest lipid percentage, followed by Navicula sp., Nannochloropsis $\mathrm{sp}$. presents the highest composition of proteins and can be potentially used for food and feed, while Guinardia $\mathrm{sp}$. is mostly composed by carbohydrates, cellulose and hemicellulose, and could be used for reducing sugars production and transformation to third generation bioethanol. Profile more suitable for the development of a topology of biorefinery corresponds to Amphiprora sp. owing to their balanced composition of lipid and non-lipid components.

Table 1. Microalgae strains composition modified from UIS-ICP-Morrosquillo [5].

\begin{tabular}{|c|c|c|c|c|c|}
\hline & Guinardia sp. & Closterium sp. & Amphiprora sp. & Navicula sp. & Nannochloropsis sp. \\
\hline Lipids (\%) & 13 & 19 & 33 & 32 & 23 \\
\hline $\begin{array}{c}\text { Cellulosic Material } \\
\text { (\%) }\end{array}$ & 35 & 17 & 20 & 12 & 18 \\
\hline Carbohydrates (\%) & 13 & 14 & 12 & 9 & 3 \\
\hline Proteins (\%) & 29 & 40 & 25 & 37 & 46 \\
\hline Ash (\%) & 10 & 10 & 10 & 10 & 10 \\
\hline
\end{tabular}

\subsection{Oil extraction efficiency}

As is shown in table 2, extraction efficiency depends as extraction method performed as microalgae strain used, according to extraction results is clear that microalgae strain Amphiprora sp. presents the highest oil yield for all five methods evaluated, followed by Navicula sp. except when EHE method is performed, this behavior can be explained from the biologic point of view owing to these two strains belong to the Naviculales order, which presents seams in their valvs, while the strain Nannochloropsis sp. whose cell wall is composed by several xylan layers making difficult chemical disruption and decreasing extraction efficiency. Guinardia sp. microalgae strain presents the highest reproducibility of third generation energy crops studied, this can be owed to a very low percentage of polar lipids and chlorophylls, which increases the standard deviations when selective and non-selective methods are compared, however, relative extraction ratio is lower than values obtained for Amphiprora sp., Navicula sp. and Closterium sp. 
Table 2. Extraction efficiency results.

\begin{tabular}{|l|c|c|c|c|c|}
\hline & \multicolumn{5}{|c|}{ Relative extraction ratio (\%) } \\
\hline Strain & SCE & EHE & HBE & CBE & SHE \\
\hline Nannochloropsis sp. & $10.65 \pm 0.37$ & $4.87 \pm 0.13$ & $16.75 \pm 7.87$ & $15.15 \pm 1.72$ & $100.00 \pm 1.71$ \\
\hline Amphiprora sp. & $92.04 \pm 2.60$ & $43.66 \pm 2.10$ & $74.52 \pm 2.40$ & $72.49 \pm 3.90$ & $100.00 \pm 1.90$ \\
\hline Navicula sp. & $73.06 \pm 7.35$ & $22.01 \pm 2.48$ & $64.05 \pm 3.66$ & $68.39 \pm 2.39$ & $100.00 \pm 1.65$ \\
\hline Closterium sp. & $50.57 \pm 10.50$ & $22.62 \pm 4.90$ & $36.15 \pm 0.40$ & $29.04 \pm 4.00$ & $100.00 \pm 1.10$ \\
\hline Guinardia sp. & $13.15 \pm 1.00$ & $9.28 \pm 1.70$ & $9.55 \pm 3.60$ & $12.83 \pm 0.40$ & $100.00 \pm 1.70$ \\
\hline
\end{tabular}

Figure 1 shows the lipid extracts obtained after performing oil extraction methods evaluated in this study, which are from left to right CSE, SHE, EHE, HBE and $\mathrm{CBE}$. By comparing relative extraction ratio of methods evaluated in five strains can be seen that continuous reflux solvent extraction method (SCE) presents the highest average relative extraction ratio, being potentially used for effective lipid extraction in lab scale, however, the scaling-up of this method can represent a process design challenge, owing to equipment, energy and solvent requirements. Batch methods as hexane and cyclohexane based extraction (HBE and CBE respectively) presents good extraction ratios in comparison to SCE method, with the advantage of an easier scaling-up, and lower solvent requirements, HBE extraction can be more attractive for a large scale microalgae processing owing to solvent cost, under local conditions, cyclohexane can be up to 13 times more expensive than hexane, cost influence on extraction methods performed in lab-scale will be studied in further sections of this work. Oil extraction using the ethanol-hexane mixture presents the lowest average standard deviation of methods evaluated which could be positive for ensure reproducibility of the oil extraction, however relative extraction ratio of this method does not overcome relative extraction ratio of any other method evaluated for the same strain.

Figure 1. Lipid extracts from microalgae obtained in lab-scale.
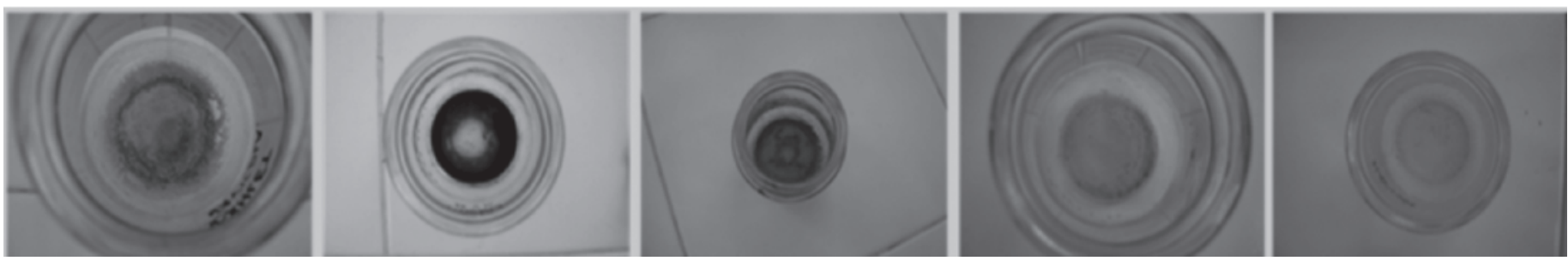

\subsection{Morphological response to oil extraction.}

After observation of cells before extraction process can be seen that Amphiprora sp. strain presents an irregular shape which is not common in diatoms (figure 2. a), this phenomenon can be derived of previous stages of microalgae biomass production chain as drying, in which some cell wall components can be degraded because of high temperature used for this step.

After performing SHE extraction using this biomass (figure 2. b), can be observed significant changes in the morphology of the cell as the presence of chloroplast outside of the cell and changes in shape and colour of the cell, this changes are promoted by two main factors, mechanical destruction by high speed homogenization and effectiveness of solvents mixture used for microalgae compounds removal, however, degree of cell destruction confirms the low selectivity of SHE method for extraction of lipids usable in biodiesel production. When biomass is submitted to SCE method can be seen that microalgae cell wall is still present although is drastically deformed and damaged, is also shown that most of intracellular content including lipids was released, hexane could break through the degraded cell wall dissolving neutral lipids and other non-polar components (figure 2. c). 
Figure 2. Morphologycal response of Amphiprora sp. strain to SHE oil extraction method (b) and SCE (c) in lab-scale. Left image correspond to cells before oil extraction (a).

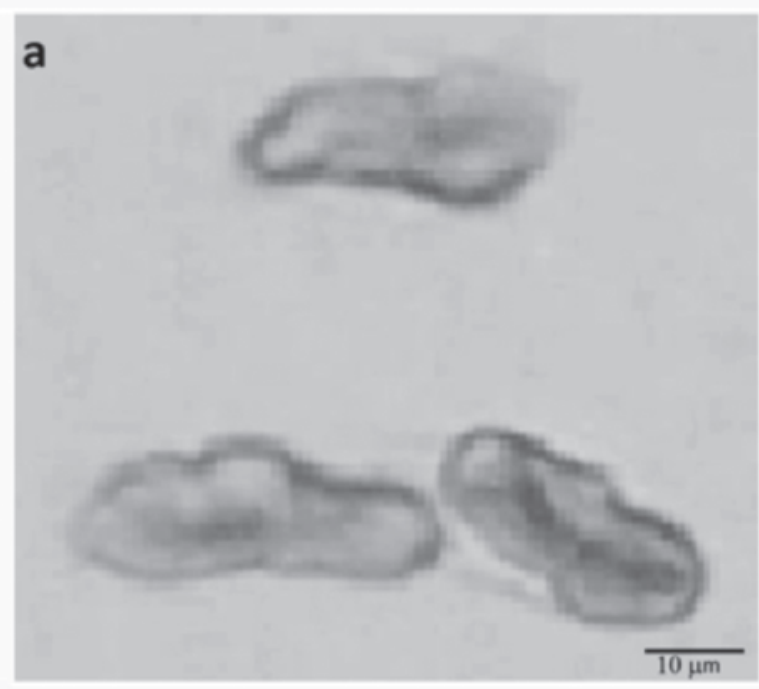

For Navicula sp. microalgae biomass can be seen that morphology of the cell is not affected by previous drying step (figure 3. a), this is due to the thickness of the microalgae frustule, which protects the cell from external damage factors. After oil extraction using EHE method (figure 3. b), can be still found cells without damage and other with most of metabolites present within the cell, this morphological response helps to explain the low efficiency of EHE method in comparison to other microalgae oil extraction methods evaluated, figure 3. c shows microalgae biomass after performing HBE method where can be seen a higher percentage of broken cell walls in comparison to EHE method, can be observed several chloroplast outside of the cell which means that metabolites were released, but were not dragged by the solvent, behaviour of microalgae biomass after CBE method performing was very similar (figure 3. d), this observation confirms the selectivity of non-polar solvent based extraction methods to microalgae lipids.

Figure 3. Morphologycal response of Navicula sp. strain to EHE oil extraction method (b) HBE method(c) and CBE method (d) in lab-scale. Left image correspond to cells before oil extraction (a).
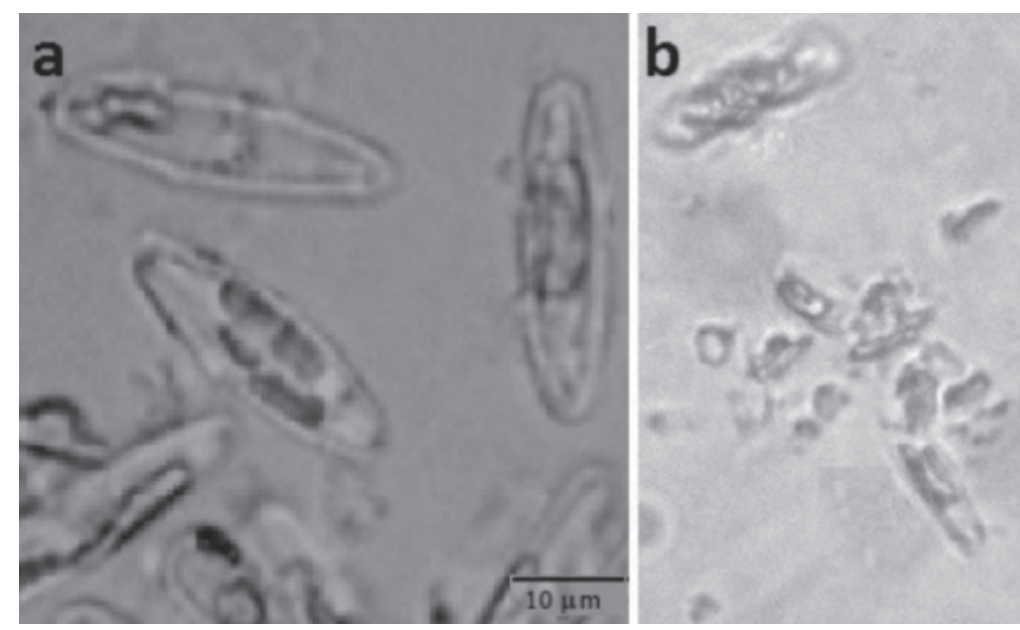
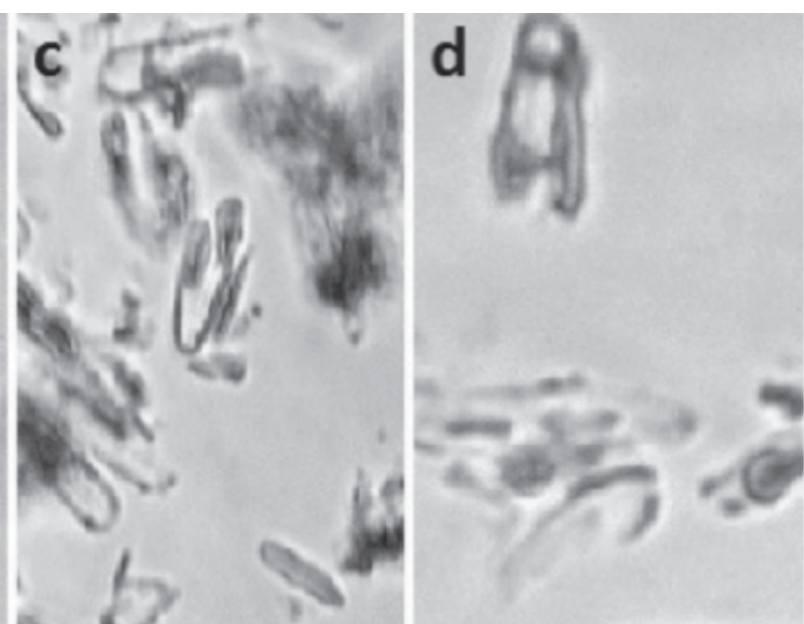

Morphological comparison of a microalgae strain to all oil extraction methods performed was made using the strain Guinardia sp. (figure 4.), when this microalgae is submitted to SHE extraction the cell shape is strongly affected and broken, can be seen pieces of frustules, free chloroplasts and other fragments of totally destroyed cells (figure 4. b), cells after EHE method keeps still their frustules, the only significant change observed by optic microscopy is related to the shape of the strain, all cells individually observed keeps their two 
chloroplasts within the cell wall (figure 4. c), with performing of CBE extraction can be observed cell disruption in several cells and absence of lipid drops which were extracted by cyclohexane in higher percentage than other methods (figure 4. d), microalgae exposed to HBE method showed a change in cell shape and cell disruption in high percentage evidenced by the presence of free chloroplasts, in come cells there was not disruption but inner metabolites looks disordered dis- located (figure 4. d), finally, when microalgae strain is submitted to SCE method there is a higher percentage of non-broken cells, however, this method presented the higher Relative efficiency, this behaviour can be explained because SCE method does not use mechanical or magnetic stirring, for this reason the possibility of cell rupture by mechanical action is lower, but solvent can remove lipid components going across the damaged cell wall (figure 4. f).

Figure 4. Morphologycal response of Guinardia sp. strain to SHE oil extraction method (b), EHE method (c), CBE method (d), HBE method (e) and CSE method (f) in lab-scale. Left image correspond to cells before oil extraction (a).
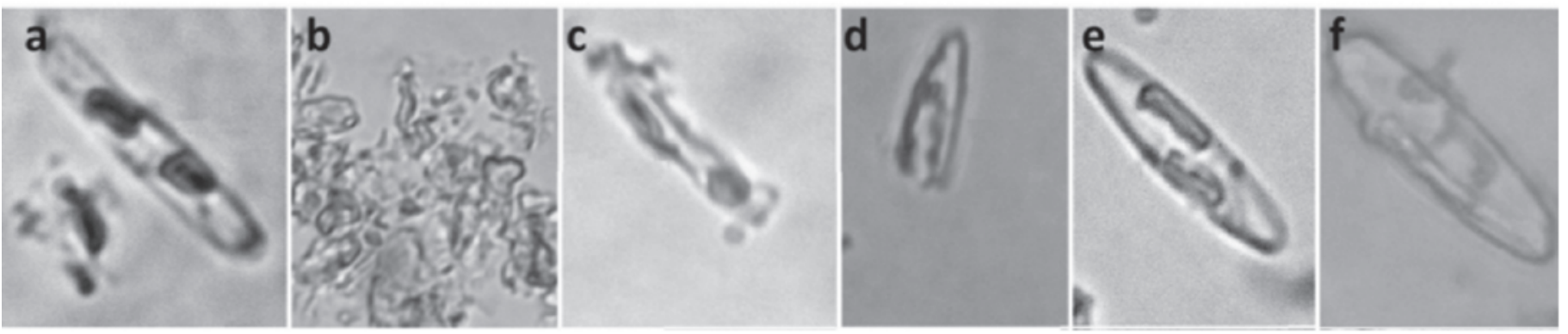

\subsection{Comparison of oil extraction methods in lab-scale}

Table 3 shows the values calculated for each oil extraction method studied taking into account energy requirements, toxicity of solvents used and estimated extraction costs in lab-scale, in order to obtain a better data analysis, values were normalized to the same biomass amount ( $1 \mathrm{~g}$ of dry biomass) and extraction time $(1 \mathrm{~h})$. It can be seen that lower energy requirements corresponds to SHE method followed by HBE/CBE and highest energy requirements are presented by SCE method, this difference can be explained by the heating and cooling requirements that soxhlet extraction system needs, extraction methods with high energy requirements must be discarded for a large scale microalgae processing if the final use of microalgae components is energetic, EHE method pre- sents high energy requirements and low efficiency as is shown in previous section. If extraction costs in lab-scale are compared, lowest value belongs to EHE method and followed by EHE method, these values are due to low solvents amount needed to perform these methods and low cost of ethanol and hexane in comparison to other organic solvents, while higher extraction costs belongs to CBE method, which is drastically increased by the costs of cyclohexane which is near to 13 times more expensive than hexane in local conditions. Finally, comparison of toxicity values of solvents used shows that SHE method is the most harmful of methods evaluated, owing to the use of highly toxic solvents as methanol and chloroform which is disadvantageous for a large-scale processing, extraction methods which uses hexane as solvent (SCE and $\mathrm{HBE}$ ) presents the lowest toxicity.

Table 3. Comparison of oil extraction methods in lab-scale.

\begin{tabular}{|c|c|c|c|}
\hline Method & $\begin{array}{c}\text { Energy } \\
\text { consumption } \\
{[\mathrm{KW} \text { h] }}\end{array}$ & $\begin{array}{c}\text { Cost of extraction } \\
\text { [USD/g of biomass] }\end{array}$ & $\begin{array}{c}\mathbf{L D}_{\text {50\% }} \\
{[\mathbf{m g} / \mathbf{K g}]}\end{array}$ \\
\hline SHE & 0.72 & 0.28 & 1194 \\
\hline SCE & 2.37 & 1.90 & 28710 \\
\hline CBE & 1.51 & 2.39 & 6200 \\
\hline HBE & 1.51 & 0.18 & 28710 \\
\hline EHE & 1.75 & 0.11 & 10600 \\
\hline
\end{tabular}


Taking into account results obtained in table 3 , can be established that for a lab-scale microalgae oil extraction, method most convenient to perform is $\mathrm{HBE}$, because its low energy consumption compared to other methods, low extraction costs and relatively low toxicity of solvent used, on the other hand, CBE method becomes non-convenient for oil extraction from microalgae due to its high cost of cyclohexane and high toxicity, in addition, lipid yield obtained with this method is similar to yields of HBE method.

\section{CONCLUSIONS}

- $\quad$ Five microalgae oil extraction methods were evaluated and compared in lab-scale (Continuous Reflux Solvent Extraction, Solvent Extraction with High Speed Homogenization, Hexane-Based Extraction, CyclohexaneBased Extraction and Oil Extraction using the mixture Ethanol-Hexane), extractions were performed using five bioprospected microalgae strains Nannochloropsis sp., Amphiprora sp., Navicula sp., Closterium sp. and Guinardia sp., general characterization of algae strains shows that Amphiprora sp. presents the highest lipid percentage and significant percentages of carbohydrates and proteins, followed by Navicula sp. and Nannochloropsis sp. SHE method was taken as reference for calculating extraction efficiency, in general terms, SCE extraction showed the highest average extraction efficiency for microalgae genera studied, followed by HBE and CBE methods, EHE method presented the poorest performance in strains evaluated, Amphiprora sp. presented the highest oil yield of strains evaluated for all five extraction methods, followed by Navicula sp., while Nannochloropsis sp. presented the lowest oil yield for all methods studied. Taking into account biomass composition, morphologic response and oil yield, microalgae genera Amphiprora sp. emerges as a potential strain for the development of a topology of biorefinery.

- Comparison of oil extraction methods taking into account all selection criteria, shows that SHE, SCE, CBE and EHE presents at least one extreme value within ranges obtained. HBE method is the most convenient to perform in lab-scale due to the high $\mathrm{LD}_{50 \%}$ of hexane, low energy requirements in comparison to other methods evaluated and low cost of extraction. Is recommendable to study the behaviour of this kind of emerging technologies for microalgae oil extraction in a large scale process in order to define the most convenient for implementation in industrial level, for this purpose, can be used tools as process simulation and energy analysis.

\section{Acknowledments}

The authors thank to the Ministry of agriculture and rural development for its support with project 2008D32006-6710
"Bioprospecting of Colombian microalgae for biodiesel production", the Colombian Petroleum Institute ICP-ECOPETROL, the administrative department of science, technology and innovation COLCIENCIAS for supporting this work through Francisco Jose de Caldas Scholarship Programs and project "Creation and strength of a knowledge and technology transfer network between United States and Colombia for the development of biorefinery processes for obtaining biofuels and high value products from microalgae biomass"., to Diana Alvarez, Catalina Molano, Julian Rueda, Jairo García and Jesus Miranda for excellent technical assistance in experimental part and to Morrosquillo Corporation.

\section{Nomenclature}

$\mathrm{w} \_\mathrm{i}$ : Variable weighting value assigned to particular criteria.

$\mathrm{m}_{0}$ : Initial amount of biomass subjected to extraction of certain specie.

$\mathrm{m}_{\mathrm{p}}$ : Amount of biomass obtained after pre-treatment.

$\mathrm{m}_{\mathrm{e}}$ : Amount of extract obtained after carrying out certain method.

Oild Yield:Main value which makes possible the comparison of the methods in different species.

$\mathrm{E}_{\text {met }}$ : Energy requirements of a given method.

$P_{\text {eq }}:$ Nominal electric power of equipment.

$t_{\text {eq }}$ : Time of use of equipment.

n: Number of equipment used to perform a given method.

$\mathrm{C}_{\text {met }}:$ Cost of application of certain method.

$\mathrm{C}_{\text {slov }}$ : Cost of a specific solvent per volume units.

$\mathrm{V}_{\text {slov }}:$ Volume of solvent used in a given method.

others: Estimated cost of other materials used in the application of each method.

$\mathrm{m}$ : Number of solvents used performing a given method.

$\mathrm{LD}_{50 \%}$ : Median Lethal Dose of a substance used as indicator of its acute toxicity.

\section{REFERENCES}

[1] Singh. PN., Singh, A., Production of liquid biofuels from renewable resources, Progr Energ Combust Sci, 37(1), 52-68, 2011. 
[2] Chisti, Y., A bioeconomy vision of sustainability, Biofuels Bioprod Biorefin, 4, 359-61, 2010.

[3] Lam, MK., Lee, KT., Microalgae biofuels: A critical review of issues, problems and the way forward, Biotechnol Adv., 30(3), 673-90, 2012.

[4] Khoo, HH., Sharratt, PN., Das, P., Balasubramanian, RK., Naraharisetti, PK., Shaik, S., Life cycle energy and $\mathrm{CO}_{2}$ analysis of microalgae-to-biodiesel: Preliminary results and comparisons, Bioresour Technol., 102, 5800-07, 2011.

[5] UIS-ICP-Morrosquillo, Bioprospecting of Colombian microalgae for biodiesel production, Final Report, Bucaramanga, 2011.

[6] Cherubini, F., The biorefinery concept: using biomass instead of oil for producing energy and chemicals, Energy Convers Manage, 51, 1412-21, 2010.

[7] González-Delgado, AD., Kafarov, V., Microalgae based biorefinery: Issues to consider, CT\&F Cienc Tecnol Future, 4(4), 5-21, 2011.

[8] Singh, J., Gu, S., Commercialization potential of microalgae for biofuels production, Renew Sustain Energy Rev, 14, 2596-610, 2010.

[9] González, A., Kafarov, V., Design of a multifunctional reactor for third generation biofuels production, Chem Eng Transact, 21, 1297-302, 2010.

[10] Henriques, M., Silva, A., Rocha, J., Extraction and quantification of pigments from a marine: A simple and reproducible method, Commun Curr Res Educ Top Trends Appl Microbiol, 1, 586-93, 2007.

[11] Peñaranda, LA., Sepúlveda, KJ., Álvarez, YE., González-Delgado, AD., Kafarov, V., Evaluation of lipid and monosaccharide obtaining routes of microalgae biomass under the biorefinery concept, Ion, 24(2), 13-22. 2011.

[12] Wilkie, A., Mulbry, W., Recovery of dairy manure nutrients by benthic freshwater algae, Bioresour Technol, 84(1), 81-91, 2002.
[13] Harun, R., Singh, M., Forde, G., Danquah, M., Bioprocess engineering of microalgae to produce a variety of consumer products, Renew Sust Energ Rev, 14, 1037-47, 2010.

[14] Mussgnug, J., Klassen, V., Schlüter, A., Kruse, O., Microalgae as substrates for fermentative biogas production in a combined biorefinery concept, J Biotechnol., 150(1), 51-6, 2010.

[15] González, AD., Kafarov, V., Guzmán, A., Development of a methodology of microalgae oil extraction in the biodiesel from microalgae production chain, Prospectiva, 7, 53-60, 2009.

[16] González, AD., Kafarov, V., Design and adjustment of coupled methods of microalgae oil extraction for third generation biofuels production in a topology of biorefinery, Prospectiva, 10(1), 113-123, 2012.

[17] Córdoba, LS., López, LM., González, AD., Kafarov, V., Diseño de una metodología para la extracción de aceite de microalgas nativas mediante el método soxhlet, Book of abstracts, XXIX Latin American Chemistry Congress CLAQ 2010, ISBN 978-958-99607-0-7: S. N. MYE 113.

[18] Fajardo, AR., Cerdan, LE., Medina, AR., Fernandez, FGA., Moreno, PAG., Grima, EM., Lipid extraction from the microalga Phaeodactylum tricornutum, Eur J Lipid Sci Technol 2007, 109, 120-6, 2010.

[19] Sarmiento, R., Amaya, A., González, AD., Kafarov, V., Desarrollo de una metodología para la extracción de aceite de microalgas empleando disrupción celular térmica y química, Book of abstracts. XXIX Latin American Chemistry Congress - CLAQ 2010. ISBN 978-958-99607-0-7: S. N. FQT 64. 2010.

[20] Galindo, L., González, S., González, AD., Kafarov, V., Adaptation of the Bligh \& Dyer method to the extraction of lipids of native microalgae for biodiesel production, Book of abstracts, XXIX Latin American Chemistry Congress CLAQ. ISBN 978-958-99607-0-7 2010: S. N. MYE 18. 2010.

[21] García, J., Miranda, J., González, AD., Kafarov, V., Comparison of microalgae oil extraction methods for biodiesel production, Book of abstracts, IV International Congress of Biofuels Science and Technology CIBSCOL:81. 2010. 